\title{
The Role of Regional Strategies in Sustainable Development: The Approach of City Plan
}

\author{
Mustafa Polat ${ }^{\mathrm{a}}$, Korhan Arun ${ }^{\mathrm{b}}$ \\ ${ }^{a}$ Turkish Military Academy, Ankara, 06000, Turkey \\ ${ }^{b}$ Department of Business Administration, Namik Kemal University, Tekirdag 59000, Turkey
}

\begin{abstract}
In the world economy and development, understanding changes are occurring, with the EU integration process of developments and understanding of planning priorities when considered as together, "city" scale development approach and an appropriate planning system, that is the basis of Turkey's administrative division and the national management system, should be improved selfrises. To reduce disparities among regions to an acceptable level and development of relatively underdeveloped regions and cities, naturally, a development and planning system even starting from the city and province levels, is required. In today's sustainable understanding and evolution tools, burden important functions to local units, as "participation" in the foreground stands out in the stages of planning and execution of the development strategies. Regional and city development plans and strategies as the center of rapid and balanced development dynamics are sensitive to local needs and local initiatives are required in being a trigger level. The study is done with Goal Directed Project Management methodology, and in the study city level taken as an example of city scale development approach and an appropriate planning system.
\end{abstract}

Keywords: Sustainable Development, Regional Strategies, City Plan Approach, City Innovation, Goal Directed Project Management.

JEL Code: Q01; O18; O21; O22

\section{Introduction}

The human component, in increasing and provisioning productivity of constituting groups and structures, was understood at least as important as physical factors after 1929 the world economic crisis. After the economic crisis, it is understood that the human element, in other words, the ideas of internal and external clients are likewise important that their preferences should be brought into thoughtfulness. Just giving importance to people is not enough for sustainable growth and productivity, from the 1950s quests are directed towards planning, strategy and providing competitive advantage. In this context of the planning functions as the long-term planning functions, planning, corporate planning, strategic planning and strategic management are possible to identify the aspects that have been applied. Turkish Public Administration practice is dominated more every day by Strategic management philosophy, the step, Provincial Development Plans prepared and implemented at the City - Province - Turkey development axis, that will occupy Turkey's development strategy is considered as important.

When the changes, occurring in the understanding of the world economy and development, and at the Turkish planning priorities taken together, starting from "city" scale development and an appropriate planning system that is

\footnotetext{
${ }^{a}$ Turkish Military Academy, Ankara, Turkey, Tel: +904462239841

${ }^{b}$ Department of Business Administration, Namik Kemal University, Degirmenalti Yerleskesi.,Tekirdag 59000, Turkey, Tel: +902822522822 ,
} 
the basis of the administrative division and the national management system approach should be developed spontaneously arises. To reduce disparities among regions to an acceptable level and for the development of a relatively underdeveloped region, naturally, city and even starting from province levels, creation of a development and the planning system is required. Today's development approach and tools essential functions to local units, foreground "participation" in the installing the preparation and implementation stages of the development strategies stands out. Rapid and balanced development of our country; is possible with the participation of all stakeholders in planning and implementation processes, as well as the public sector, private sector, civil society organizations, professional associations, universities, and other citizens. Therefore, a well-attended city development plans should be created with institutionalization and solidarity efforts. City development plans and strategies according to 9th Development Plan (2007-2013), the center responsive to local needs and dynamics and triggering local initiatives as a level are required for rapid and balanced development.

With the help of City Development Plan in the Turkish Government's $9^{\text {th }}$ Development Plan (2007-2013); all institutions and organizations in the city shall give direction to the short, medium and long term development, general trends may be identified and future projections can be coordinated. Superior areas in the city may be determined, specializing in existing and prospective sector in the development will be provided. Thus, the city development strategies will fulfill a function that feeds, mobilizing local resources and potential, raises our socioeconomic level at underdeveloped regions, providing rural development and the realization of national plans and programs. It will contribute to the strengthening of local government (authorities). It will strengthen the local economy and locality awareness of economic, social, cultural initiatives that can be routed and will be supported. Thus, plans and preferences made with society's demands, requirements, and capabilities, should be sufficiently taken into account. Local planning efforts are replicated at the local level will trigger an embodiment of total planned in local institutions and local governments. Local participation and local democracy arrangements can be made to occur, which emphasizes strengthening provincial governance in terms of an authority and resources. In such a system, provincial and province administrations will coordinate public services and investments by harmonizing macroeconomic policies and practices. Decision-making authority on local services will be transferred to local decision makers, administrative system gain more democratic qualification; thus, political and social culture of the countryside will be positively affected. Development will start from province- city scale. Launching the Development from city scale, in terms of the country's development, gives the public opportunity to easily and willingly participate in the burden of the services to rural areas. So the relationship between the service demand and its load, will be established. It will facilitate the prompting of local potential so idle capacity use will be reduced; small and medium-sized enterprises and entrepreneurs will participate effectively in the economy. Through city development strategies; the economic potential of local and regional resources can be prompted; the provincial socioeconomic level can be raised in a fair and balanced manner; rural development can be contributed, a function that supports the realization of national plans and programs can be fulfilled. Fulfillment of this function is closely related, to the city development planning done effectively and efficiently and implementation of the identified strategies. Also financial architectures which will elevate the development depend on indigenous supplies of equity (Pike, Rodríguez-Pose \& Tomaney, 2011:363). For these reasons, the overall development of the country is of great importance in the achievement of city development plans. However, during the planned development; although local (territorial) administrative officials, given the duties and responsibilities in this direction, to provide rapid and balanced development of legal and administrative measures could not be taken as needed as a result the development of the legal environment and conditions could not be established enough (Turkish Government's $9^{\text {th }}$ Development Plan (2007-2013)).

\section{Implementation of City Development Plan in Turkey}

In Turkey, of the past 10-15 years the provincial development plan preparation process has been gaining pace especially with the $9^{\text {th }}$ Development Plan (2007-2013). The purpose of prepared City Development Plans, are providing a continuous and sustainable development planning consistent with the objectives and policies of national and regional development plans, using the resources of the city rationally. The plans are examined in detail and comprehensive studies that what to be done for the development of the city, and the economic, social and 
infrastructure sectors, in terms of the environment. Plans take; development based on City's own resources and environmentally sensitive, spreading this development between provinces from the center to surrounding towns, economic and social disparities are minimized, development of the human resources and institutional capacity and resource use efficiency in the provision as a basis. Analysis of the current situation, the cast for the province's strengths and weaknesses an analysis of environmental and cyclical conditions creating opportunities and threats to the City; to carry as a guide for public authorities, private sector, community leaders, and for people living in the province; provide guidance in making decisions regarding the city intended in the Plan. Plan have led to all stakeholders, in the city, to think together on issues of the city, to design and manufacture a common future, will guide the development of provincial objectives, strategies and development projects. It is seen in the plans prepared that studies conducted in nine areas of study come to the fore. These areas; Population and Social Structure; Income Distribution, Poverty and Employment; Human Resources: Education, Culture, Health; Technical Infrastructure: Transportation, Communication, Energy, Water and Sewerage; Agriculture; industry; Services: Tourism, Trade, Construction, Banking and Financial Structure; Environment and Spatial Development and Management and Corporate structure.

Plans in all sectors and at each stage were carried out using several methods. During the process of identification and analysis of the current situation; technical literature review, province and corporate visits, field studies, surveys, specialized commission meetings, face-to-face interviews and meetings were held with the pioneers. In addition to local public bodies and institutions data and technical support has been taken from the government Planning Organization, government Institute of Statistics, Treasury, General Directorate of Highways, General Directorate of Land Registry and Cadaster from institutions from the central government. To inform the City about the Plan, to assure survey and fieldwork participation, in cooperation with Governors for introduction of the significance and scope of the provincial development plans, and works in the plan a booklet printed and was distributed to specialized commission members, industrial workplaces and in the provinces concerned. The full text of this booklet into a series of several days to be published in local newspapers are provided. On the websites Opened in the first months of the study and are still active, promotion booklet text, interim reports and industry reports have been provided, in an updated format that can be easily downloaded, and about the reach of every moment to who concerned.

In addition, protocols made with Governors and a city Development Plan to include the following topics are decided to be prepared:

A-Current Situation Analysis (Sectorial and Spatial Presence)

B-Sectorial and Spatial Problems and Bottlenecks

C-City Development Strategy, Principles and Policy Objectives

D-Medium-and Long-Term Needs

E-Medium and Long Term Development Perspectives

F-Participation, Financing Resources and Organization

G-Sector Projects

H-Action Plan

\subsection{University-Industry-Government Collaboration Requirements for City Development Plan}

When we look at Competition history, the competition of superiority may be expressed in the 1960 production, in the 1970s cost, in the 1980s, quality, and in the 1990s the speed and capacity, and at present including all of them got along with the information management. To obtain information, to own and manage it is a complex, expensive process that requires and research, innovation and diversity, companies' collaboration how much needed with others is revealed. With collaboration and the development of local technological infrastructure help of venture capitalists 
new ideas and proving concepts, that innovative knowledge economies may play an integral part (Pike, RodríguezPose \& Tomaney, 2011:356)

In terms of Universities, scientific research is costly, in time, less cost of conducting research ideas came to the fore, so of this quest universities give priority to research that could solve the problems of the industry. Since the invention of writing, science and technology have become so close to each other for the first time. Science, started to take into account in technology, in other words, requests and demands of people have.

At the present governments' characteristics of the law-making and rule-making and feature increasingly gained importance, but so is observed that a de facto retreat from the production area. In this context, government as a facilitator and mediator effect, in university-industry cooperation and coordination are observed.

Nowadays how the issues that are necessary the university-industry-government partnerships are not focused on. The problem we face today, can be expressed as these three players with different strategic goals, what areas, how long and the detection of will comes together to what ability to develop.

The development of social welfare depends on taking effectively advantages of scientific and technological work. The task of the modern government; is to prepare the organizations to improve the welfare of society. Scientific and technological developments may be provided the use of existing facilities within a short period. Development is provided by making scientific thought in society as a lifestyle. One of the most important tools to convert knowledge into production is the university-industry cooperation. The fundamental and theoretical knowledge obtained in the universities into practice as a means of converting beautiful university-industry collaboration are used in various countries. Through this cooperation, technological knowledge with the needs of industry is transferred from universities to companies. Cooperation of these organizations is needed in terms of rational use of scarce resources (Yücel, 2007).

Contemporary development strategies support holistic development efforts economic, rather than social, industrial, rural development which are distinctly separated development approach. The quality of economic growth is directly proportional to how much of the holistic approach is sustainable. Sustainability, beyond creating on the economic added value, can be carried out with a model, whether the active participation of local actors is included in the management process (Dulupçu et al., 2007).

$\mathrm{R} \& \mathrm{D}$ and innovation work is of utmost importance during the time that Globalization has increased at a constant rate and taken in a brutal competition nowadays. Businesses a companies or nations' economy on macro basis first priorities in these conditions is to produce information-technology to continually evolve to survive. Collaboration with industry is necessary for Universities that to convert produced knowledge, into technology and product. In many countries, university-industry collaboration, meet the technology needs of industry, although the industry also provides an opportunity of practical applications to universities. This mutual cooperation is accelerating the economic development of countries. Cooperation and solidarity between industry and university in Turkey is not at the desired level, as is the university's integration with the industry has been below the desired dimensions. Here the effect of not introducing universities themselves, as good as industries having the lack of a structure directing to technological research has the important role (Şenol, 2010).

In order to be the industry able to profit and grow, manufacturing needs to be improved and increased. This is possible with adaptation technological inventions and innovations into the production. An adaptation of the industry to new technologies, design and production organization must be reconstructed; production methods and techniques must be performed. Technology and adaptation of technology to the industry has been a ring that connects universities and the industry. More research and development needs to be heard for Industry breasting competition and opening to the world market. Only in this way technological capabilities will be able to increase (Yalçiner, 2007).

Common goals of University-Industry Cooperation, can be considered to redefine new and important areas of research, long-term cooperation between science and industry, to develop pre-competitive research to encourage cooperation, make use of embedded (tacit) knowledge at large and permanent, make to provide focus on critical 
knowledge density and cooperation guidance to R \& D. Cooperation centers in the realization of this objective are of great importance in terms of contribution to the national economy. Thus, they provide; increases in industrial R \& D capacity, applied research and critical alliances are provided, the structures required for international cooperation, national R \& D plans to be implemented and the best R \& D management and culture development.

Collaboration is difficult in any case. Especially the mission and expectations diametrically opposed cooperation between university and industry is even more difficult. To ensure the success of all these elements to the specified prerequisite ready to cooperate is the existence of a system that encourages and facilitates. It will be possible considering the philosophy of all three parties and following a unifying path steps that have to be taken by the government.

An indispensable requirement of cooperation between university and industry, in recent years a very complex and multi-actor model of university-industry collaboration has led to the emergence of. Briefly, trying to bring solutions to problems and to the well suited needs of the parties, institutional structures that can be called "interface" institutions, techno parks, technology transfer centers, incubators and centers of the type of cooperation are becoming increasingly important (Kiper, 2010).

In Turkey, there isn't a serious dialogue between organizations which are the public and private sectors, the university, driving force for academic and industrial research. The private sector to compete seriously and respond to domestic and international market demand, make commercial use of the information must be converted by establishing dialogue with universities and research institutions in R\&D (Söylemez \& Ünsan, 2004).

\subsection{Sample Applications can be used in the Cooperation}

- Support to Industrial $R \& D$ Projects

- Scientific and Technological $R \&$ D Support Program

- Public R \& D Projects Support Program

- Support Program for Industrial Thesis

- Cooperation Networks and Program Support Program

- Project Market Platform Support Program

- Technology Development Zones

- Technology Development Centers

- University-Industry Joint Research Centers Program

- Carried out by the University Curriculum and Contract-Based Projects

- University Revolving Fund System with Contract-Based Projects

- University Continuing Education Centers

- Career Programs through Collaboration with Industry

- Collaboration Purpose University Institutes and Centers

- Technology Transfer Offices

\subsection{Issues to Be Considered in Preparation of City Development Plan}

Plans developed for the City will also offer reinforcement and build infrastructure to the national perspective of a regional growth program. Consequently, the objectives and details of the plan formulation process are significant. A plan prepared in the framework of University-Industry-Government cooperation, will benefit both in preparation and 
in the implementation of the plan because there is a positive correlation between technological innovation rates and increasing city size (Haughton \& Hunter, 2003:67). Consequently, the methods to be utilized will also contain ingredients to ensure the success of the program.

\section{City Development Plan Model}

A- Introduction: Legal Basis, Purpose, Scope, Methods, Expressions of Interest Statement

B- Present Situation Analysis (Sectorial and Spatial Condition): Population and Social Structure, Income Distribution, Poverty and Employment, Human Resources (Education, Culture, Health), Technical Infrastructure (Transportation, Communications, Energy, Water and Sewer), Agriculture, industry, Services (Tourism, Trade, Construction, Banking and Financial Structure), Environment and Spatial Development, Managerial and Organizational Structure

C- $\quad$ Sectorial and Spatial Problems and Bottlenecks

D- City Development Strategies, Principles, Objectives and Policies: Vision, Guiding Principles, Objectives, Policies, and Alternative Development Scenarios

E- $\quad$ Needs: Short, Medium and Long Term

F- Development Perspectives: Short, Medium, Long Term

G- Participation, Financing Resources and Organization

H- $\quad$ Sector Projects: Infrastructure Projects, Human Resource Projects, IT Projects, Power Projects, Environmentrelated Projects, Agriculture Projects, Industrial Projects, Service Projects, Cooperation Requiring Joint Projects, Administrative Projects

İ- $\quad$ Action Plan: Development, Monitoring, Plan Adoption, Practice

J- City Development Strategy

\section{Method of Preparation of City Development Plan Proposal (Enhanced Goal Directed Project Management)}

\subsection{Goal Directed Project Management}

Goal Directed Project Management (Öner \& Başoğlu, 2000; Betz, 1993) sheds light on how to forward a methodological approach to the subject for a successful project planning, execution and evaluation methods and tools necessary for the purposes of the project. Comes to project management techniques, P-S-O (People (P) -System (S) Organization $(\mathrm{O})$ ), taking into account all the factors in the concept of the project is to bring a different approach to management. With the addition of knowledge management today to these three concepts of K-P-S-O concept has occurred (Öner \& Başoğlu, 2000). In Table 1, Goal Directed Project Management methodology is shown schematically and project planning, organization and control stages of the methodology necessary for the mode of administration is given information about the activities and documentation.

Project Assignment Form (Project Directive), contained in Project planning section, is a document containing the current situation that already analyzed and the purpose of the project. Parsing Objective Statement provides the project's boundaries to be drawn significantly more accurate and the designation of objectives. Phase Indicators Plan, is an overall plan showing the progress steps of the project, shows what to reach the end of the stage, and how it can be measured.

Key Responsibilities Statement, contained in the documents of Project organization, includes the allocation of resources and distribution of responsibility and authority project under the direction of the organization being carried out. Responsibility Statement Table of the project, is a table that identifies who is in the stage of determining responsibility in achieving project's goal to reach. Activity Responsibility Statement, however, is also more detailed 
planning study to determine who will work in order to achieve the planned activities to a certain stage and to plan a timetable for activities.

Control of the operation of the project is monitored with a variety of reports. And the project (Responsibility) Report is the statement of compliance reports, Phase Indicators Report shows how the project is progressing according to the stage indicators plan, latter report controls compliances according to responsibilities table. Annual Report has applied for, reporting in detail the developments in the project work study.

Table 1 Goal Directed Project Management Methodology

\begin{tabular}{|c|c|c|c|}
\hline Level / Position & Project Planning & Project Planning & Project Planning \\
\hline $\begin{array}{l}\text { General Level } \\
\text { (Project Level) }\end{array}$ & $\begin{array}{l}\text { Project Assignment Form } \\
\text { Parsing Objective Statement } \\
\text { Indicators Step Plan }\end{array}$ & $\begin{array}{l}\text { Key Responsibilities } \\
\text { Statement } \\
\text { Project Responsibility } \\
\text { Statement }\end{array}$ & $\begin{array}{l}\text { Phase Indicators Report } \\
\text { Project Report }\end{array}$ \\
\hline
\end{tabular}

Degree of Detail

Responsibility Statement of Operations

(Activity Level)

(Operations Plan)

Annual Report

\section{2. $K-P-S-O$ Projects}

K-P-S-O (Knowledge-People-System-Organization) concept, is regarded a different angle of approach to project management, as a concept. Information technology management is seen as the first use of this type of project experience in many of the computer systems used in organizations and work on projects in mind only the technical side of the system implementation have proved generally unsuccessful.

Mostly a product of the development of the project in terms of physical creation and excessive concentration on technical aspects, will cause of neglect of training and motivation of people who will use the product. Also today, the importance of diffusion of innovation is increasingly hopping, reveals that the Rebuilding the organizational structure and organizational factors also should be considered in project management.

Therefore, providing the four factors in the concept of K-P-S-O or in other words, the forces in line with each other to take part in a project is considered as an inevitable result of an effective project management system. Goal directed project management technique is a project management technique advocating and implementing that these four factors should be evaluated together.

"K" (Knowledge), factor in the concept of the K-P-S-O, is used to provide individual and organizational aspects of knowledge sharing that is required for the project management. Healthy functioning of information management systems to the success of the project is one of the preconditions.

"P" letter symbolizes the human factor in project management systems (structure of the project will be created) and represent the necessity to ensure a balance between people and organization. The people factor to be overlooked or ignored are the factors most important to constitute an obstacle to the success of the project. The contribution of different cultures, in the terms of the knowledge and behavior created within the project group, as well as the adoption of the project by the members of all groups is very important for the success of the project.

"S" or "system" concept, encompasses all the technological facets of the project. Usually, the portion of the project is related to concrete aspects. System-related developments can be clearly and easily observed or assessed. Product development in the "new product"; in the construction project "buildings or bridges"; in the merger of two companies project, the emerging "new company" are assessed as a system. 
Letter "O" or organization factor, allows planning to be done by taking into account the structure of the organization concerned the project management. Structure and functioning of the organization have a very direct and significant impact on achieving the determined objectives of the project.

K-P-S-O projects create a unified project that contains all project issues. They comprise the elements of Processoriented and expertise projects together and shall be involved to relate the elements with each other.

The use of K-P-S-O concepts, provides to think in more detail on the project and the creation of a broader perspective what is contained in the project. It would be wrong to expect the success of the project aims to approach if just focused on the Single "S" factor, or vice versa development of the relationship between individuals. Said with a wide perspective of the project taking into consideration four factors to be managed together as the natural result will bring success. Tables, prepared in connection with City Development Plan Model proposal, and which will be developed with the participation of all interested parties of the project, are presented below (Appendix-A-F).

\section{Conclusion}

The main element that will provide social and economic development in the City; is a feasible plan, with the support and participation of representative groups and ideas that will be generated by all groups across the province. Therefore, instead of developing a particular product, ensuring an environment to develop products in all sectors emerge as primary of effort. Subsequent process, innovations and developments in products will emerge more easily.

The effects of globalization can be seen with each passing day more and more nowadays, to keep the narrow domain of the cities in the region in the province plans is seen as a significant obstacle to regional and national entrepreneurship. Therefore, instead of focusing on a place geographically to focus on one aspect of specific sectors / products will be more useful. There cannot be a development plan Regardless of geography, but, in the same way to see the geography only as the restricting effect might lead to misdirection.

In the realization of the project will be made within the framework of Project Objective Directed Project Management philosophy to take into account; knowledge, people, systems and organizations of all sizes. Thus, the project is not only on paper, the rest of the project can be demonstrated more clearly in terms of things to do what can be done, especially in the human dimension, within the terms of knowledge and management.

This proposal rather than focusing on a specific product, have been directed to the area generally considered to be incomplete for the development of the province. Meeting at a common point on the main road that the city will go, also bring improvements in the secondary roads. Mistakes will be made at the strategic level is not able to compensate with tactical success; the aim of the project is to establish the forming the city's overall strategy among of all the stakeholders. Thus, the main development areas and other secondary roads can be determined in the context of this main road route may be shaped more easily.

As a result, development plans to be created in the cities will contribute in many different areas in developing projects. The projects foreseen, with participation of all stakeholders and developing a common mind; can be made into projects risk relatively low but greater gain. Duplication of projects can be avoided by collecting of all the work done in the cities in the same pool. An appropriate structure for the solution of problems where industry and university partners, can be created by providing in support of the government and will provide a leading role played in the creation of development plans for other cities in the region.

\section{References}

Betz, F. (1993). Strategic Technology Management. Singapore: McGraw-Hill Co.

Dulupçu, M.A. \& Sungur, O. (2007). Yenilik, İşbirliği ve Girişimcilik Batı Akdeniz Bölgesi (Antalya-Burdur-Isparta, İBBS TR61). KOBI' lerinin Tutumlarının Değerlendirilmesi. Ankara. 
Haughton G. \& Hunter C. (2003). Sustainable Cities. UK.:Routledge.

Kiper, M. (2010). Dünyada ve Türkiye'de Üniversite-Sanayi İşbirliği ve Bu Kapsamda Üniversite-Sanayi Ortak Araştırma Merkezleri Programı (ÜSAMP). Ankara: İşkur Matbaacılık. Türkiye Teknoloji Geliştirme Vakfı (TTGV) Yayını.

Pike A., Rodríguez-Pose A. \& Tomaney J. (2011). Handbook of Local and Regional Development, New York: Routledge.

Öner, M.A. \& Başoğlu, N. (2000). "Knowledge, People, System and Organization Framework", Research Note, Manufacturing and Technology Strategies Research Group, İstanbul.

Söylemez, M. \& Ünsan, Y. (2004). “Gemi İnşaatı Sanayi-Üniversite İşbirliği; Sorunlar, Çözümler ve Türkiye Gerçekleri“ Gemi Mühendisliği ve Sanayimiz Sempozyumu.

Şenol O. (2010). "Pamukkale Üniversitesi Öğretim Elemanlarının Üniversite Sanayi İşbirliğinde Karşılaştıkları Sorunlara İlişkin Bir Alan Araştırması“, Sosyal Gelişim Dergisi, Vol.:1 Number.:1 June http://www.sosyalgelisim.net.

Turkish Government's $9^{\text {th }}$ Development Plan. (2006). Bölgesel Gelişme Özel İhtisas Komisyonu İl Gelişme Stratejileri ve Politikaları Alt Komisyon Raporu. Ankara.

Yalçıner, A.Y. (2007). “Üniversite-Sanayi İşbirliği: Beklentiler, Sorunlar ve Fırsatlar”, USİS 2007, Üniversite Sanayi İsbirliği Sempozyumu, pp. 336-345. Sakarya.

Yücel, I.H. (2007) "Bilim-Teknoloji Politikaları ve 21. Yüzyılın Toplumu“, http://ekutup.dpt.gov.tr/bilim/, 09.12.2010, web., BILTEK 07. Ankara:,DPT.

\section{$\underline{\text { Appendix }}$}

Appendix A: Example Project Documents

Main Project Directive - 2014-001 (Recommendations)

NAME

OWNER

MANAGER

BEFORE

OBJECTIVES

GOALS

CONSTRAINTS

RISKS

ESTIMATED TIME

BUDGET

RELATED PROJECTS 
Appendix B: Main Project Purpose Separation Statement

\section{MISSION / PURPOSE:}

\begin{tabular}{|c|c|c|c|c|c|}
\hline $\begin{array}{l}\text { To ensure enforcement of the } \\
\text { Plan in accordance with the } \\
\text { proactive management } \\
\text { approach }\end{array}$ & \begin{tabular}{|l}
$\begin{array}{l}\text { Core Objective-1 } \\
\text { (Knowledge) }\end{array}$ \\
Plan to meet the \\
requirements in the \\
knowledge dimension.
\end{tabular} & \begin{tabular}{|l} 
Core Target-2 \\
(People)
\end{tabular} & \begin{tabular}{|l} 
Core Target 3 \\
(System) \\
To take the necessary \\
measures To demonstrate \\
and the preparation of the \\
Plan
\end{tabular} & $\begin{array}{l}\text { Core Target-4 } \\
\text { (Organization) } \\
\text { To provide the plan necessary } \\
\text { organization, preparation and } \\
\text { methodology determination. }\end{array}$ & $\begin{array}{l}\text { Support } \\
\text { Ensure the active participation of } \\
\text { support units to the plan. }\end{array}$ \\
\hline $\begin{array}{l}\text { Y-1 To ensure that the } \\
\text { decisions taken During the } \\
\text { project be implemented. }\end{array}$ & $\begin{array}{l}\text { 101- Training of project } \\
\text { groups. }\end{array}$ & $\begin{array}{l}\text { 201- Identification of the } \\
\text { project and the project } \\
\text { manager of the group. }\end{array}$ & $\begin{array}{l}\text { 301- Identification and } \\
\text { preparation work of the } \\
\text { office for plans. }\end{array}$ & $\begin{array}{l}\text { 401- Exercise of coordination } \\
\text { meetings in cooperation } \\
\text { between the parties of } \\
\text { University, State and Industry. }\end{array}$ & $\begin{array}{l}\text { D-1 Timely transfer of } \\
\text { information to ensure University- } \\
\text { Industry-Government } \\
\text { Collaboration from units. }\end{array}$ \\
\hline $\begin{array}{l}\text { Y-2 Monitoring of the plan } \\
\text { adoption process legally. }\end{array}$ & $\begin{array}{l}\text { 102-Plans related articles } \\
\text { in academic journals and } \\
\text { the special issue at the } \\
\text { university in the City to be } \\
\text { published. }\end{array}$ & $\begin{array}{l}\text { 202- To reveal the action } \\
\text { plan will be conducted to } \\
\text { Manufacturers, Traders, } \\
\text { Public Administrators and } \\
\text { academics for students with } \\
\text { a Bachelor and Master's } \\
\text { Degree. }\end{array}$ & $\begin{array}{l}\text { 302- Printing and } \\
\text { duplication of the Plan. }\end{array}$ & $\begin{array}{l}\text { 402- The identification of } \\
\text { techniques and methods to be } \\
\text { applied in cooperation with the } \\
\text { University, government and } \\
\text { Industry }\end{array}$ & $\begin{array}{l}\text { D-2 In defining and } \\
\text { Implementing Legislative } \\
\text { changes taking support of } \\
\text { relevant Departments. }\end{array}$ \\
\hline $\begin{array}{l}\text { Y-3 To guarantee the } \\
\text { sustainability of the project. }\end{array}$ & $\begin{array}{l}\text { 103- University } \\
\text { undergraduate and } \\
\text { graduate thesis to be } \\
\text { associated with the } \\
\text { development plan. }\end{array}$ & $\begin{array}{l}\text { 203- Establishment of a } \\
\text { performance management } \\
\text { system in line with the } \\
\text { Development plans. }\end{array}$ & $\begin{array}{l}\text { 303- Establishment of } \\
\text { networks among university- } \\
\text { industry and government } \\
\text { agencies which are related to } \\
\text { planning and software } \\
\text { development. }\end{array}$ & $\begin{array}{l}403 \text { - Determining the order of } \\
\text { priority of the projects under } \\
\text { the plan. }\end{array}$ & $\begin{array}{l}\text { D-3 Provision of financial } \\
\text { resources for the project. }\end{array}$ \\
\hline $\begin{array}{l}\text { Y-4 Monitoring the legislative } \\
\text { changes that plan would } \\
\text { require and ensure the } \\
\text { implementation of the } \\
\text { necessary changes. . }\end{array}$ & $\begin{array}{l}\text { 104-The enforcement of } \\
\text { Entrepreneurship, patents } \\
\text { and innovation courses } \\
\text { and programs. }\end{array}$ & $\begin{array}{l}\text { 204- Creating of HRM policy, } \\
\text { preparation of the dynamic } \\
\text { human resources plan and } \\
\text { directing towards the } \\
\text { project. }\end{array}$ & & & \\
\hline $\begin{array}{l}\text { Y-5 Proactive management of } \\
\text { university-industry } \\
\text { collaboration. . }\end{array}$ & & $\begin{array}{l}\text { 205- Preparation and } \\
\text { implementation of training } \\
\text { plans. }\end{array}$ & & & \\
\hline $\begin{array}{l}\text { Y- } 6 \text { Close monitoring and } \\
\text { modification of the plan. }\end{array}$ & & & & & \\
\hline
\end{tabular}


Appendix C: City Development Plan Main Project Responsibility Statement (Recommendation)

\begin{tabular}{|c|c|c|c|c|c|c|c|c|c|c|c|c|c|c|c|c|c|c|c|c|c|c|c|c|c|c|c|c|c|}
\hline & ITY DEVI & ELOP & ME & & LA & & & & \multirow{2}{*}{\multicolumn{2}{|c|}{$\begin{array}{l}\text { U: Executive } \\
\text { K: Decision alone } \\
\text { k: take decisions together } \\
\text { Y: Manager } \\
\text { E: Instructor } \\
\text { D: should be consulted } \\
\text { B: Should be informed } \\
\text { T: Can be taken advice } \\
\text { Approved by / Date }\end{array}$}} & \multirow{2}{*}{ 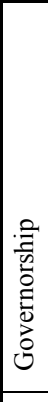 } & \multirow{2}{*}{ 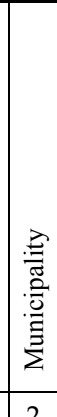 } & \multirow{2}{*}{ 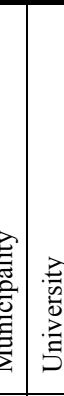 } & \multirow{2}{*}{ 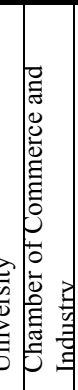 } & \multirow{2}{*}{ 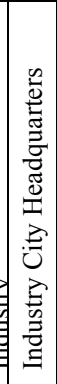 } & \multirow{2}{*}{ } & \multirow{2}{*}{ 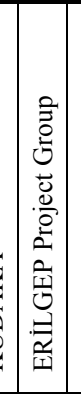 } & \multirow{2}{*}{$\varangle$} & \multirow{2}{*}{ 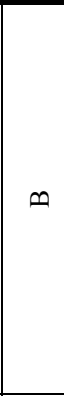 } & \multirow{2}{*}{$\cup$} & \multirow{2}{*}{ ๑ } & \multirow{2}{*}{ 디 } & \multirow{2}{*}{ 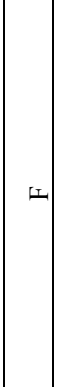 } & \multirow{2}{*}{0} & \multirow{2}{*}{ \pm} & \multirow{2}{*}{-} & \multirow{2}{*}{$\neg$} & \multirow{2}{*}{$\checkmark$} & \multirow{2}{*}{ - } \\
\hline \multirow{2}{*}{\begin{tabular}{l|} 
Time \\
Month
\end{tabular}} & \multirow[t]{2}{*}{ Start Date } & \multicolumn{6}{|c|}{ Period length 2 months } & \multirow{2}{*}{$\begin{array}{l}\text { Completion } \\
\text { Date }\end{array}$} & & & & & & & & & & & & & & & & & & & & & \\
\hline & & & & & & & & & No & PROJECTS & 1 & 2 & 3 & 4 & 5 & 6 & 7 & 8 & 9 & 10 & 11 & 12 & 13 & 14 & 15 & 16 & 17 & 18 & 19 \\
\hline 1 & 01.02 .2015 & $\rightarrow$ & & & & & & 01.03.2015 & 101 & Training of project groups. & B & $\mathrm{B}$ & $\mathrm{E}$ & k & $\mathrm{D}$ & $\mathrm{k}$ & $\mathrm{U}$ & & & & & & & & & & & & \\
\hline 10 & 01.03 .2015 & & & & & & & 01.01.2016 & 102 & $\begin{array}{l}\text { Articles in academic journals at the } \\
\text { universities in the city and the special } \\
\text { issue to be published related plans. }\end{array}$ & B & $\mathrm{B}$ & $\mathrm{U}$ & $\mathrm{T}$ & $\mathrm{D}$ & $\mathrm{k}$ & $\mathrm{k}$ & & & & & & & & & & & & \\
\hline 10 & 01.03 .2015 & & & & & & & 01.01 .2016 & 103 & $\begin{array}{l}\text { University undergraduate and } \\
\text { graduate thesis to be associated with } \\
\text { the development plan. }\end{array}$ & B & B & $\begin{array}{l}\mathrm{K} \\
\mathrm{U}\end{array}$ & $\mathrm{D}$ & $\mathrm{D}$ & $\mathrm{D}$ & $\mathrm{D}$ & & & & & & & & & & & & \\
\hline 10 & 01.03 .2015 & & & & & & & 01.01 .2016 & 104 & $\begin{array}{l}\text { The enforcement of Entrepreneurship, } \\
\text { patents and innovation courses and } \\
\text { programs. }\end{array}$ & B & B & $\mathrm{E}$ & $\mathrm{D}$ & $\mathrm{T}$ & $\mathrm{k}$ & $\begin{array}{l}\mathrm{k} \\
\mathrm{U}\end{array}$ & & & & & & & & & & & & \\
\hline 1 & 01.01 .2015 & $\rightarrow$ & & & & & & 01.02 .2015 & 201 & $\begin{array}{l}\text { Identification of the project and the } \\
\text { project manager of the group. }\end{array}$ & k & $\mathrm{T}$ & $\mathrm{T}$ & $\mathbf{k}$ & $\mathrm{T}$ & & & & & & & & & & & & & & \\
\hline 1 & 01.02 .2015 & & & & & & & 01.03 .2015 & 202 & $\begin{array}{l}\text { Revealing the action plan will be } \\
\text { conducted to Manufacturers, Traders, } \\
\text { Public Administrators and academics } \\
\text { for students with a Bachelor and } \\
\text { Master's Degree. }\end{array}$ & B & B & E & $\mathrm{T}$ & $\mathrm{T}$ & $\mathrm{T}$ & $\begin{array}{l}\mathrm{K} \\
\mathrm{U} \\
\mathrm{Y}\end{array}$ & & & & & & & & & & & & \\
\hline 1 & 01.03 .2015 & & & & & & & 01.04 .2015 & 203 & $\begin{array}{l}\text { Establishment of a performance } \\
\text { management system in line with the } \\
\text { Development plans. }\end{array}$ & B & B & $\mathrm{E}$ & $\mathrm{T}$ & $\mathrm{T}$ & $\mathrm{D}$ & \begin{tabular}{|l|}
$\mathrm{K}$ \\
$\mathrm{U}$ \\
$\mathrm{Y}$ \\
\end{tabular} & & & & & & & & & & & & \\
\hline 1 & 01.03 .2015 & & & & & & & 01.04 .2015 & 204 & $\begin{array}{l}\text { HRM policy creation, preparation of } \\
\text { the dynamic human resources plans } \\
\text { and directed towards the projects. }\end{array}$ & B & B & E & $\mathrm{T}$ & $\mathrm{T}$ & $\mathrm{D}$ & \begin{tabular}{|l|}
$\mathrm{K}$ \\
$\mathrm{U}$ \\
$\mathrm{Y}$ \\
\end{tabular} & & & & & & & & & & & & \\
\hline 1 & 01.01 .2015 & $\rightarrow$ & & & & & & 01.02 .2015 & 205 & $\begin{array}{l}\text { Preparation and implementation of } \\
\text { training plans. }\end{array}$ & B & $\mathrm{T}$ & $\begin{array}{l}\mathrm{D} \\
\mathrm{E}\end{array}$ & $\mathrm{k}$ & $\mathrm{T}$ & B & $\begin{array}{l}\mathrm{k} \\
\mathrm{U} \\
\mathrm{Y}\end{array}$ & & & & & & & & & & & & \\
\hline
\end{tabular}




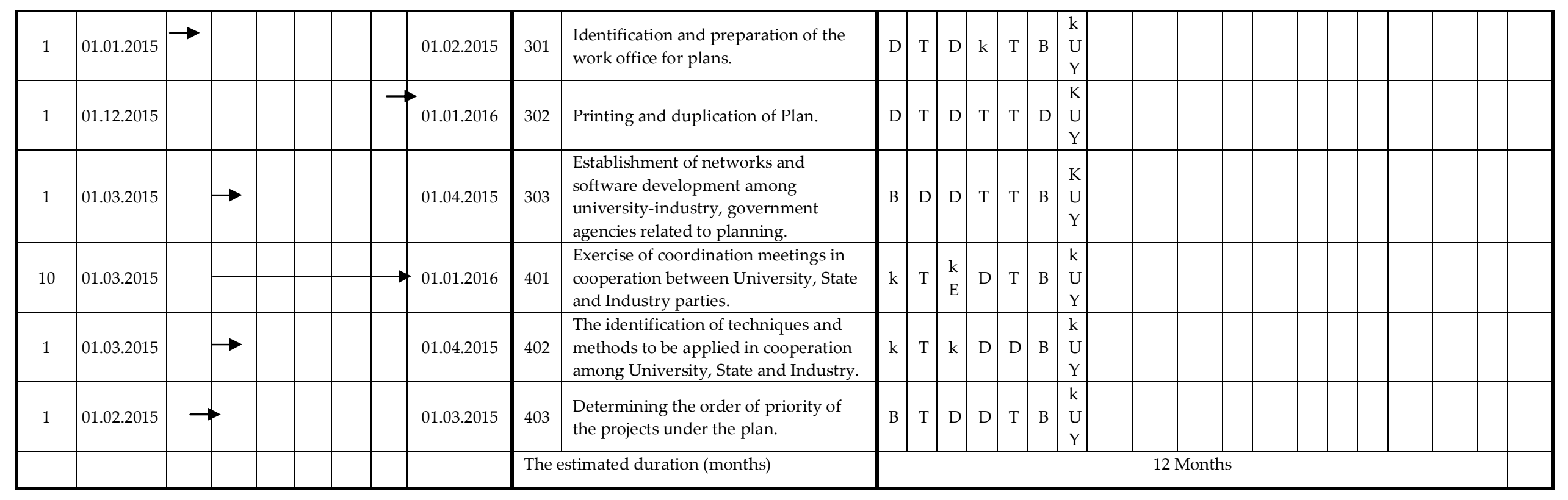


Appendix D: City Development Plan's Indicators Plan (Recommendation)

\begin{tabular}{|c|c|c|c|c|c|c|c|c|c|c|c|c|c|c|c|c|}
\hline \multirow[t]{2}{*}{ Ay } & \multirow[t]{2}{*}{ Start Date } & \multicolumn{12}{|c|}{1 PERIOD = 1 MONTH } & \multirow{2}{*}{$\begin{array}{c}\text { Completion } \\
\text { Date }\end{array}$} & \multirow[t]{2}{*}{ No } & \multirow[t]{2}{*}{ STEP INDICATORS } \\
\hline & & 1 & 2 & 3 & 4 & 5 & 6 & 7 & 8 & 9 & 10 & 11 & 12 & & & \\
\hline 1 & 01.01 .2015 & & & & & & & & & & & & & 01.02 .2015 & 201 & $\begin{array}{l}\text { Detection of Project group and the } \\
\text { project manager }\end{array}$ \\
\hline 1 & 01.01 .2015 & & & & & & & & & & & & & 01.02 .2015 & 205 & $\begin{array}{l}\text { Preparation and implementation of } \\
\text { training plans. }\end{array}$ \\
\hline 1 & 01.01 .2015 & $t$ & & & & & & & & & & & & 01.02 .2015 & 301 & $\begin{array}{l}\text { Identification of the work office and } \\
\text { preparation for plans. }\end{array}$ \\
\hline 1 & 01.02 .2015 & & $\rightarrow$ & & & & & & & & & & & 01.03 .2015 & 101 & Training of project groups. \\
\hline 1 & 01.02 .2015 & & & & & & & & & & & & & 01.03 .2015 & 202 & $\begin{array}{l}\text { To reveal the action plan will be } \\
\text { conducted to Manufacturers, } \\
\text { Traders, Public Administrators and } \\
\text { academics for students with a } \\
\text { Bachelor and Master's Degree. }\end{array}$ \\
\hline 1 & 01.02 .2015 & & & & & & & & & & & & & 01.03 .2015 & 403 & $\begin{array}{l}\text { Determining the order of priority of the } \\
\text { projects under the plan. }\end{array}$ \\
\hline 1 & 01.03 .2015 & & & & & & & & & & & & & 01.04 .2015 & 203 & $\begin{array}{l}\text { Establishment of a performance } \\
\text { management system in line with the } \\
\text { Development plans. }\end{array}$ \\
\hline 1 & 01.03 .2015 & & & & & & & & & & & & & 01.04 .2015 & 204 & $\begin{array}{l}\text { HRM policy creation, the preparation of } \\
\text { the dynamic human resources plans and } \\
\text { directed towards projects. }\end{array}$ \\
\hline 1 & 01.03 .2015 & & & & & & & & & & & & & 01.04 .2015 & 303 & $\begin{array}{l}\text { Establishment of networks and software } \\
\text { development among university-industry } \\
\text { and government agencies concerned } \\
\text { with plan. }\end{array}$ \\
\hline 1 & 01.03 .2015 & & & $\rightarrow$ & & & & & & & & & & 01.04 .2015 & 402 & $\begin{array}{l}\text { Identification of techniques and methods } \\
\text { to be applied in cooperation with the } \\
\text { University, State and Industry. }\end{array}$ \\
\hline 10 & 01.03 .2015 & & & & & & & & & & & & & 01.01 .2016 & 102 & $\begin{array}{l}\text { Plans related articles in academic } \\
\text { journals and the special issue to be } \\
\text { published at the city university. }\end{array}$ \\
\hline 10 & 01.03 .2015 & & & & & & & & & & & & & 01.01 .2016 & 103 & $\begin{array}{l}\text { University undergraduate and graduate } \\
\text { thesis to be associated with the } \\
\text { development plan. }\end{array}$ \\
\hline 10 & 01.03 .2015 & & & & & & & & & & & & & 01.01 .2016 & 104 & $\begin{array}{l}\text { Enforcement of Entrepreneurship, } \\
\text { patents and innovation courses and } \\
\text { programs. }\end{array}$ \\
\hline 10 & 01.03 .2015 & & & & & & & & & & & & & 01.01 .2016 & 401 & $\begin{array}{l}\text { Exercise of coordination meetings in } \\
\text { cooperation between the parties } \\
\text { University, State and Industry }\end{array}$ \\
\hline 1 & 01.12 .2015 & & & & & & & & & & & & $\rightarrow$ & 01.01 .2016 & 302 & Printing and duplication of plan \\
\hline
\end{tabular}


Polat and Arun /International Journal of Research in Business and Social Science Vol 3, No 3, 2014 ISSN: 21474478

Appendix E: Project Directive and Responsibility Statement (Sample)

Project Number 201 Directive

TITLE : Detection Project group and the project manager.

OWNER : Governor's Office, University and Industry and Chamber of Commerce

MANAGER : The project will be determined by the owners.

BEFORE

OBJECTIVE : Project group who will prepare a The City development plan and to select project managers ensure that created the project group work towards the goals and objectives.

GOALS : To establish an appropriate qualification project team, to select a project manager to ensure the efficient and effective operation of the project group, to create the project group to provide university-industry-government collaboration.

CONSTRAINTS: Human resources available in the province, level of individuals' motivation who can work on the project.

$\begin{array}{ll}\text { RISKS } & :- \\ \text { ESTIMATED TIME } & : 1 \text { Month } \\ \text { BUDGET } & : 1,000 \$ .\end{array}$


Appendix F: 201 Project Number: Responsibility Statement

\begin{tabular}{|c|c|c|c|c|c|c|c|c|c|c|c|c|c|c|c|c|c|c|c|c|c|c|}
\hline \multicolumn{7}{|c|}{$\begin{array}{c}201 \text { - Establish Project group and } \\
\text { manager }\end{array}$} & \multirow{2}{*}{\multicolumn{2}{|c|}{$\begin{array}{l}\text { U: enforcer } \\
\text { K: decision-alone } \\
\text { k: take decisions together } \\
\text { Y: manager } \\
\text { E: instructor } \\
\text { D: to be consulate } \\
\text { B: to be informed } \\
\text { T: can be taken advice } \\
\text { Approved by / Date }\end{array}$}} & \multirow{3}{*}{$\begin{array}{c}\varangle \\
\\
\\
\\
1\end{array}$} & \multirow{3}{*}{$\begin{array}{l}\infty \\
\\
2\end{array}$} & \multirow{3}{*}{$\begin{array}{c}u \\
3 \\
3\end{array}$} & \multirow{3}{*}{$\begin{array}{c}0 \\
\\
4\end{array}$} & \multirow{3}{*}{$\begin{array}{l}5 \\
5 \\
5\end{array}$} & \multirow{3}{*}{$\begin{array}{l}\text { I } \\
6 \\
6\end{array}$} & \multirow{3}{*}{$\begin{array}{l}0 \\
\\
7\end{array}$} & \multirow{3}{*}{$\begin{array}{l}I \\
\\
8\end{array}$} & \multirow{3}{*}{$\begin{array}{l}\curvearrowleft \\
\\
9\end{array}$} & \multirow{3}{*}{$\begin{array}{l}\curvearrowleft \\
10 \\
10\end{array}$} & \multirow{3}{*}{$\begin{array}{l}\qquad \underline{v} \\
11\end{array}$} & \multirow{3}{*}{$\begin{array}{l}- \\
12 \\
12\end{array}$} & \multirow{3}{*}{$\begin{array}{l}\sum \\
13\end{array}$} & \multirow{3}{*}{$\begin{array}{l}\text { Z } \\
14\end{array}$} \\
\hline Time & \multirow{2}{*}{ Start Date } & \multicolumn{4}{|c|}{ Period length 1 Week } & Completion & & & & & & & & & & & & & & & & \\
\hline Week & & 1 & 2 & 3 & 4 & & No & Phase Indicators & & & & & & & & & & & & & & \\
\hline 1 & 01.01 .2015 & & $\rightarrow$ & & & 08.01 .2015 & AG- 1 & $\begin{array}{l}\text { Introduction and announcement of the } \\
\text { project }\end{array}$ & $\mathrm{K}$ & $\mathrm{k}$ & $\mathrm{k}$ & $\mathrm{k}$ & $\mathrm{T}$ & $\mathrm{T}$ & $\mathrm{T}$ & $\mathrm{T}$ & YU & $\mathrm{T}$ & $\mathrm{T}$ & $\mathrm{E}$ & $\mathrm{T}$ & $\mathrm{D}$ \\
\hline 1 & 09.01 .2015 & & & & & 16.01 .2015 & AG- 2 & $\begin{array}{l}\text { Determination of Group of candidates } \\
\text { to be included in the project, and the } \\
\text { eager staff and the manager }\end{array}$ & $\mathrm{K}$ & k & k & k & $\mathrm{T}$ & $\mathrm{T}$ & $\mathrm{T}$ & $\mathrm{T}$ & YU & $\mathrm{T}$ & $\mathrm{T}$ & $\mathrm{E}$ & $\mathrm{T}$ & $\mathrm{D}$ \\
\hline 1 & 17.01 .2015 & & & & 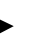 & 24.01 .2015 & AG- 3 & Discussion of candidates & K & $\mathrm{k}$ & $\mathrm{k}$ & $\mathrm{k}$ & $\mathrm{T}$ & $\mathrm{T}$ & $\mathrm{T}$ & $\mathrm{T}$ & YU & $\mathrm{T}$ & $\mathrm{T}$ & $\mathrm{E}$ & $\mathrm{T}$ & $\mathrm{D}$ \\
\hline 1 & 25.01 .2015 & & & & & 01.02 .2015 & AG- 4 & $\begin{array}{l}\text { Acceptance of the project group and } \\
\text { announcement. }\end{array}$ & B & k & k & k & $\mathrm{T}$ & $\mathrm{T}$ & $\mathrm{T}$ & $\mathrm{T}$ & YU & $\mathrm{T}$ & $\mathrm{T}$ & $\mathrm{E}$ & $\mathrm{T}$ & $\mathrm{D}$ \\
\hline & & & & & & & & Estimated Time (Days) & & & & & & & & & & & & & & \\
\hline
\end{tabular}

